International Journal of Engineering \& Technology, $7(4.20)(2018) 118-122$
International Journal of Engineering \& Technology
SPC
Website: www.sciencepubco.com/index.php/IJET
Research paper

\title{
Using Polyurethane Coating of Concrete Pipes with Acid Attack Resistance in Sewer Lines
}

\author{
Alhassan H. Ismail ${ }^{1 *}$, Basim Sh. Abed ${ }^{2 *}$ \\ ${ }^{1}$ Institute of Technology, Middle Technical University, Baghdad, Iraq. \\ ${ }^{2}$ College of Engineering, University of Baghdad, Baghdad, Iraq. \\ *Corresponding author E-mail: hassan19851988@yahoo.com
}

\begin{abstract}
One of the most important challenges facing the designers of the sewerage system is the corrosion of sewers due to the influence of sewerage contaminates which lead to failure of the main lines of sewers. In this study, a reference mix of $1: 1.5: 3$ was used and the $4 \%$ Flocrete PC200 by weight of cement was added to the same mixing ratio in the second mixture. Twenty-four samples were tested for each mixture, 12 of which were used to compression strength test in ages $(7,14$ and 28$)$ day and six samples were submerged after 28 days of wet treatment at (5 and 10) \% concentrations of sulfuric acid. The other six samples were painted after 28 days of wet treatment with coating Polyurethane and after 24 hours were flooded with a concentration of (5 and 10) \% of sulfuric acid. The results showed that the specimens coated with polyurethane paints, whether they were referenced or added 4\% Flocrete PC200, were very high resistance to corrosion, where the weight loss ratio was $0 \%$.
\end{abstract}

Keywords: acid attack, coating, concrete pipes, corrosion, polyurethane, sewer, weight loss.

\section{Introduction}

\subsection{General}

The microbial contaminants that reason erosion of solid sewer pipelines are an intense issue and costly. This erosion is as of now assaulting the sewerage framework on the planet. All inclusive, billions of dollars for every year are the misfortunes because of microbial contaminants initiated consumption breakdown of sewer funneling (Hewayde, Nehdi et al. 2007). Prior, Olmsted and Hamlin (1900) have considered the erosion occurrence of solid sewer pipelines. From there on, the scientists saw that a white pale substance shaped on eroding the entire segments of solid sewer pipelines. They reasoned that the destructive operator caused by sulphuric-corrosive yet the connection between the corrosive event and the nearness of $\mathrm{H} 2 \mathrm{~S}$ in the sewer pipelines framework was not comprehended until some decade's later (Bowlus and Banta 1932). The expansion in the force of the microbial contaminants prompted consumption issue has prompted a restored enthusiasm for the physical procedures included. This has uncovered process unpredictability and the association of numerous microorganisms species (Nica, Davis et al. 2000; Okabe, Odagiri et al. 2007) and in addition indicated parasitic species (Cho and Mori 1995; Gu, Portage et al. 1998; Nica, Davis et al. 2000).

Numerous techniques utilized for enhancing solid funnels created and utilized for sewers lines, these strategies worried about resentence of erosion caused by sulfate corrosive.

\subsection{Instrument of erosion}

Nearly the bacteriogenic corrosive assault speaks to the principle issue in sewer pipelines which run in part full (figure 1). The anaerobic microorganisms diminish sulfates in the profluent to sulfides and lead to the development of (H2S) hydrogen sulfide gas. The hydrogen sulfide gas escapes into the sewer climate then it will be conveyed to the crown of the pipe by convection process. Once there, it oxidizes to create sulfur or breaks down in dampness to shape (H2SO4) sluphuric corrosive. The two types of sulfur will be supplements for the second arrangement of oxygen consuming microbes. The predetermined bacterial activity produces sulphuric corrosive which known as biogenic sulphuric corrosive erosion. That sulphuric corrosive will assault the Portland bond mortar by dissolving the Portlandite segment $(\mathrm{Ca}(\mathrm{OH} 2)$ and calcium silicate hydrate stages, and leaving a silica gel. The concentrated harm in sewer pipelines caused by biogenic sulphuric corrosive erosion is appeared in Figure 1. (www.calucem.com).

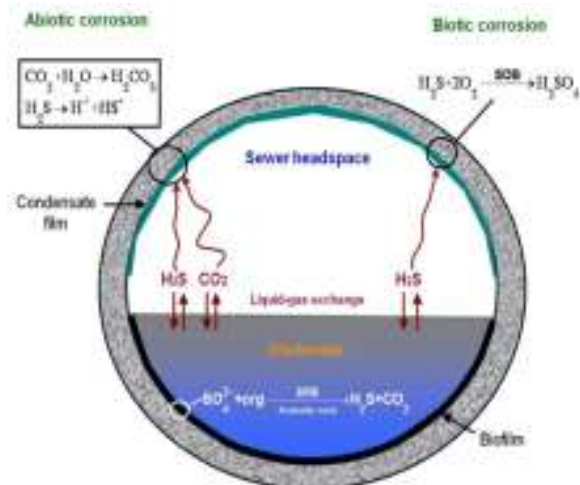

Figure 1: Mechanism of Biogenic Sulphuric Acid Corrosion 


\subsection{Objective of this Search}

Sewage networks concrete suffer from corrosion due to the presence of different concentrations of sulfuric acid. The sewage networks in the city of Baghdad is a clear example for frequent subsidence and fractures resulting from corrosion of concrete sewer pipes by acid mainly for the purpose of this study to search for materials that lead to reducing the corrosion by acids, which are:

1- Using superplasticizer to reduce the percentage of water to cement ratio and which lead to reduce the permeability of concrete.

2- Using polyurethane paint to coated the specimens and prevents penetration of sulfuric acid into specimens that cause corrosion of concrete.

\subsection{Research Significance}

The attention to sewage networks and maintain their integrity and efficiency of the performance of the most important problems of the municipalities in the different cities and the importance of this study is to attempt to efficient and continued use of the pipeline of concrete and increase resistance to corrosion acid and failure before the end of the period of service and thus will save large sums of money that will be spent on rebuilt In addition to the many problems associated with it back to the previous level. The implementation of the main sewer large diameters is accompanied by many engineering problems and obstruction the activities of daily life of the people. This study attempts to contribute to reducing this suffering and raise the efficiency of the work of sewerage concrete and prolong life to the form of discrimination that this process leads to the result is a very clear reduction in the cost of production and implementation.

\section{Materials}

\section{2-1. Coarse Aggregate}

Coarse aggregate used in this research particle size is less than 9 $\mathrm{mm}$ and greater than $1.18 \mathrm{~mm}$. Table 2-2 explain the physical and chemical properties of coarse aggregate.

\section{2-2. Fine aggregate}

Al-Ekhaider natural sand was used in the present research as the fine aggregate with particle size distribution smaller than $4.75 \mathrm{~mm}$ and greater than $0.15 \mathrm{~mm}$. Table 2-2 explains the physical and chemical properties of fine aggregate.

\subsection{Mixing water}

Potable water was used in all the mixtures that were execution in this research.

\begin{tabular}{|c|c|c|}
\hline Oxides composition & \% Content & Limits of Iraqi specification No.5/1984 \\
\hline $\mathrm{CaO}$ & 60.78 & -- \\
\hline $\mathrm{SiO}_{2}$ & 20.54 & -- \\
\hline $\mathrm{Al}_{2} \mathrm{O}_{3}$ & 5.88 & -- \\
\hline $\mathrm{Fe}_{2} \mathrm{O}_{3}$ & 3.28 & $<5.00$ \\
\hline $\mathrm{MgO}$ & 2.93 & $<2.80$ \\
\hline $\mathrm{SO}_{3}$ & 1.87 & $<4.00$ \\
\hline L.O.I. & 3.31 & $<1.5$ \\
\hline Insoluble residue & 1.15 & $0.66-1.02$ \\
\hline $\mathrm{C}_{3} \mathrm{~S}$ & 0.89 & \\
\hline $\mathrm{C}_{2} \mathrm{~S}$ & $\mathbf{M a i n}$ compounds (Bogue's equations) \\
\hline $\mathrm{C}_{3} \mathrm{~A}$ & 41.737 & \\
\hline $\mathrm{C}_{4} \mathrm{AF}$ & 27.48 & \\
\hline
\end{tabular}

\subsection{Polyurethane}

Polyurethane paints used to offer vastly superior durability and aesthetics to most other paint types, and should be considered in all cases where protection for long-term of the substrate is important, and the maintenance requirements significantly lowered to be of the desired option. In this research, polyurethane was used for floors as shown where the characteristic is superior durability for floors, $25 \%$, faster dry time, no sanding between coats and complete project in one day.

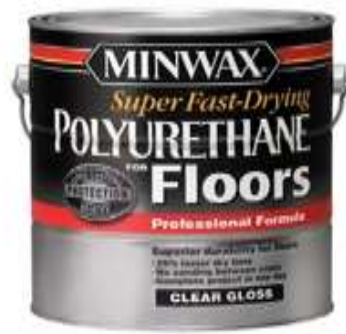

Figure 2: Polyurethane paints

Table 1: Physical and Chemical Properties of Coarse Aggregate

\begin{tabular}{|l|c|c|}
\hline Physical properties & Test Result & $\begin{array}{l}\text { Limits of Iraqi specifica- } \\
\text { tion No.45/1984 }\end{array}$ \\
\hline Specific gravity & 2.65 & - \\
\hline Absorption \% & $0.85 \%$ & - \\
\hline $\begin{array}{l}\text { Sulfate content as } \\
\mathrm{SO}_{3} \%\end{array}$ & $0.045 \%$ & $\leq 0.5$ \\
\hline Fineness modulus & 2.8 & - \\
\hline $\begin{array}{l}\text { Density dry compact- } \\
\text { ed }\end{array}$ & $1600 \mathrm{~kg} / \mathrm{m}^{3}$ & - \\
\hline
\end{tabular}

Table 2: Physical and Chemical Properties of Coarse Aggregate

\begin{tabular}{|c|c|c|}
\hline Physical properties & Test Result & $\begin{array}{c}\text { Limits of Iraqi specifica- } \\
\text { tion No.45/1984 }\end{array}$ \\
\hline Specific gravity & 2.5 & - \\
\hline Absorption \% & $1 \%$ & - \\
\hline $\begin{array}{c}\text { Sulfate content as } \\
\mathrm{SO}_{3} \%\end{array}$ & $0.1 \%$ & $\leq 0.5$ \\
\hline $\begin{array}{c}\text { Fineness modulus } \\
\text { ed }\end{array}$ & 2.8 & - \\
\hline $\begin{array}{c}\text { Density dry compact- } \\
\text { ed }\end{array}$ & $1780 \mathrm{~kg} / \mathrm{m}^{3}$ & - \\
\hline
\end{tabular}

\subsection{Cement}

Sulfate-resisting Portland cement (Type V) known commercially as (the bridge) was used throughout this research. The chemical properties of cement used in the present research are shown in Table 2-3. Test results were indicated that the adopted cement was confirmed to the Iraqi specification No.5/1984. 
Table 4: Compressive strength for various types of R and 4\% SP mixtures

\begin{tabular}{|c|c|c|c|}
\hline \multirow{2}{*}{ Mix } & \multicolumn{3}{|c|}{ Compressive Strength MPa } \\
\cline { 2 - 4 } & 7 day & 14 days & 28 days \\
\hline $\mathbf{R}$ & 30.9 & 32.1 & 36.5 \\
\hline $\mathbf{4 \% S P}$ & 42.5 & 44.03 & 49.8 \\
\hline
\end{tabular}

\subsection{Superplasticizer}

Superplasticizer is used in this research as a chemical additive to reduce water superior degree which carries the trade name Flocrete PC200 of British Production Company DCP, which is identical to the US specification (ASTM C494 Type G \& D).

\subsection{Sulfuric acid}

The sulfuric acid that used in this research is a concentration of $98 \%$ and the specific gravity 1.79

Table 5: percentage of weight loss for various types of mixture

\begin{tabular}{|c|c|c|c|c|c|c|c|c|}
\hline \multicolumn{8}{|c|}{ percentage of weight loss $(\mathrm{M} 1-\mathrm{M} 2 / \mathrm{M} 1 * 100)$} & \\
\hline \multicolumn{2}{|c|}{$\begin{array}{l}4 \% \text { SP \&Coated with } \\
\text { poly }\end{array}$} & \multicolumn{2}{|c|}{ Coated with poly } & \multicolumn{2}{|c|}{$4 \% \mathrm{SP}$} & \multicolumn{2}{|l|}{$\mathrm{R}$} & $\underbrace{0}_{0}$ \\
\hline$\% 10$ & $\% 5$ & $\% 10$ & $\% 5$ & $\% 10$ & $\% 5$ & $\% 10$ & $\% 5$ & 进 \\
\hline 0 & 0 & 0 & 0 & 3.9 & 1.8 & 21.19 & 7.2 & 1 \\
\hline 0 & 0 & 0 & 0 & 11.5 & 6.4 & 55.98 & 20.44 & 2 \\
\hline 0 & 0 & 0 & 0 & 16.6 & 9.5 & 78.44 & 34.7 & 3 \\
\hline 0 & 0 & 0 & 0 & 22.8 & 12.2 & 96.62 & 43.9 & 4 \\
\hline 0 & 0 & 0 & 0 & 33.52 & 18.3 & 100 & 52.6 & 5 \\
\hline 0 & 0 & 0 & 0 & 44.5 & 21.5 & 100 & 65.8 & 6 \\
\hline 0 & 0 & 0 & 0 & 52.6 & 27.7 & 100 & 75.9 & 7 \\
\hline 0 & 0 & 0 & 0 & 61.7 & 32.8 & 100 & 100 & 8 \\
\hline 0 & 0 & 0 & 0 & 72.3 & 37.3 & 100 & 100 & 9 \\
\hline 0 & 0 & 0 & 0 & 83.9 & 41.4 & 100 & 100 & 10 \\
\hline 0 & 0 & 0 & 0 & 100 & 47.9 & 100 & 100 & 11 \\
\hline 0 & 0 & 0 & 0 & 100 & 52.1 & 100 & 100 & 12 \\
\hline
\end{tabular}

\subsection{Curing}

After finishing casting process the specimens have been covered directly with plastic sheeting for 24 hours to prevent the evaporation of water from the soft specimens, after that take out the specimens of the templates there treated in moist treatment for 28 days under the American standard (ASTM-C 192 / 02)

\subsection{Immersion in sulfuric acid}

Specimens submerged at age 28 in concentration (5 and 10)\% of sulfuric acid every weekend are weighed and measured the dimensions of the specimens after washing and brushing clean it and

\subsection{Mixtures of laboratory}

This search included two mixtures for each mixture of 24 specimens as follow:

1- $\quad$ The reference mix where the mixing ratio $1: 1.5: 3$ and water/cement ratio equal to 0.48 for this mix included 24 specimens, 12 specimens for the compression test, 6 specimens coated with polyurethane (coated with poly) and another 6 without coating $(\mathrm{R})$.

2- Used mixing ratio (1: $1.5: 3)$, water/cement ratio equal to 0.28 and 4\%SP (Flocrete PC200). This mix included 24 specimens, 12 specimens for the compression test, 6 specimens coated with polyurethane (4\%SP \& coated with poly) and another 6 specimens without coating $(4 \% \mathrm{SP})$.

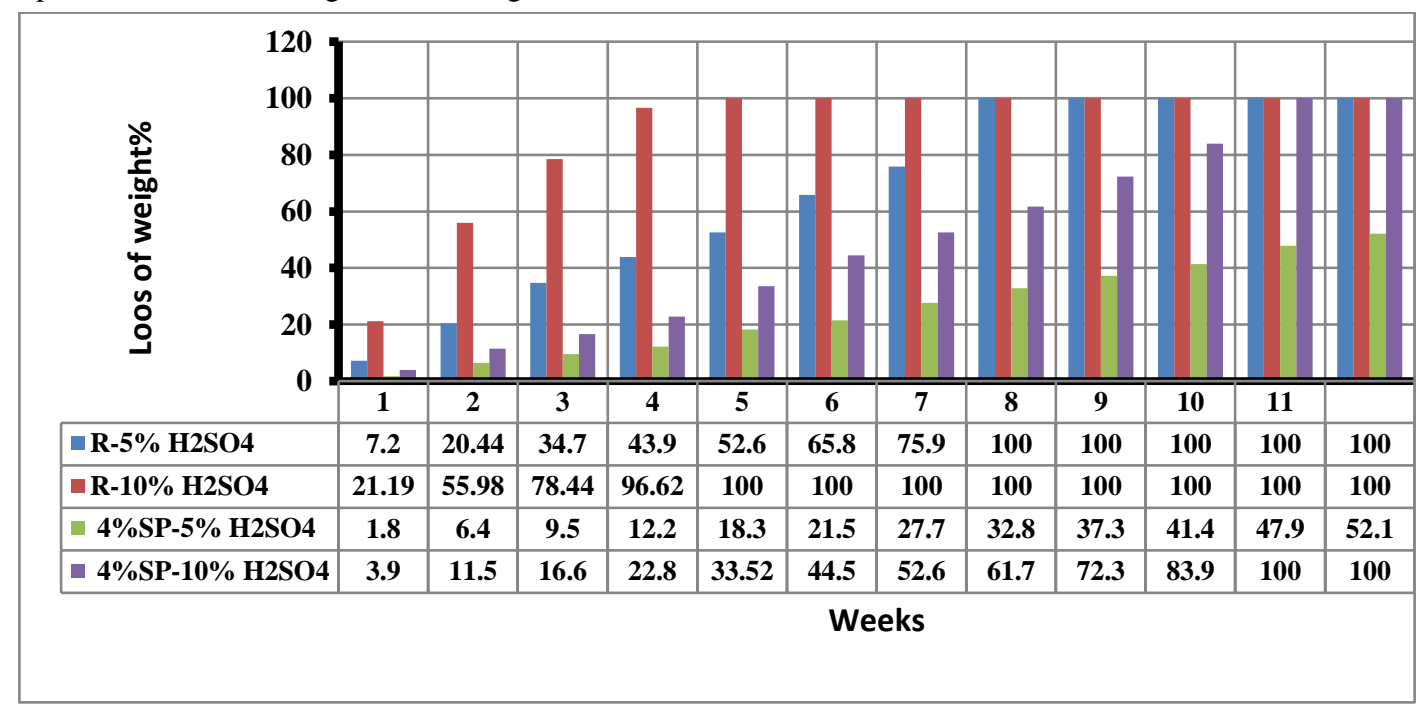

Figure 4: Explain the loss of weight for reference and 4\%SP mix immersed in diluted sulfuric acid with weeks. 


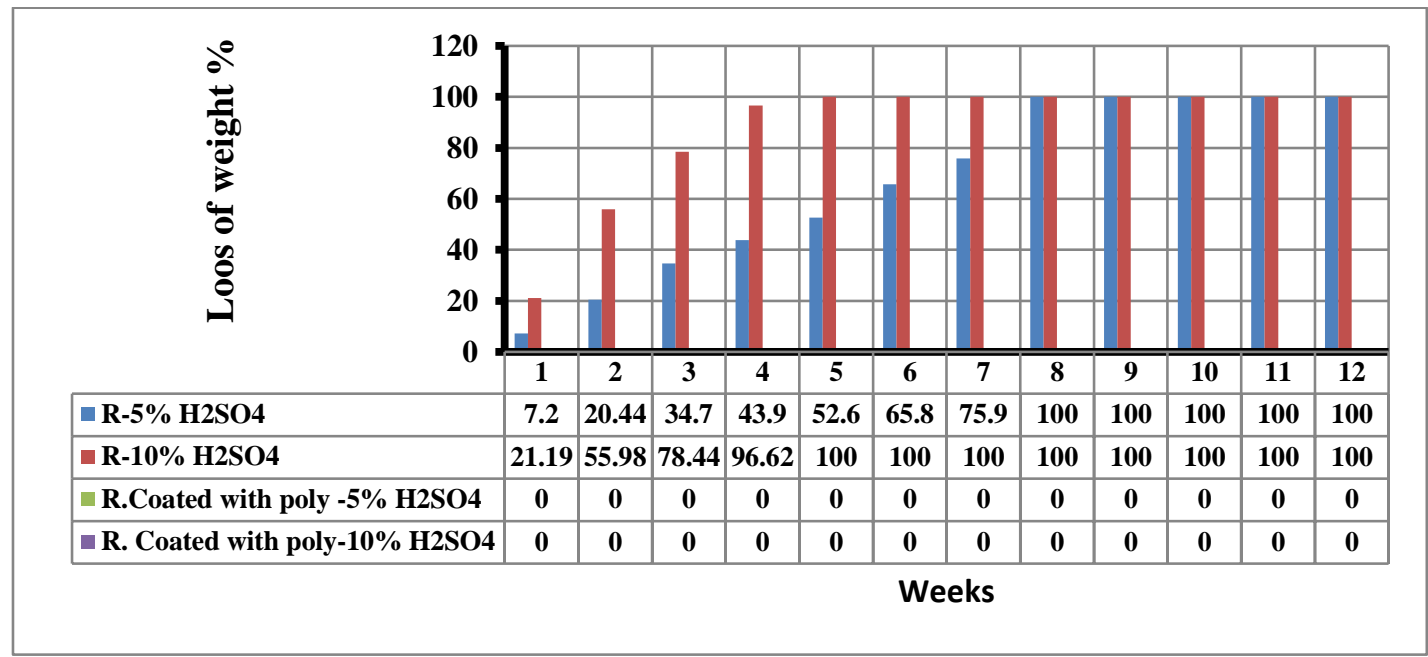

Figure 5: Explain the loss of weight for reference specimens coated with polyurethane immersed in diluted sulfuric acid with weeks.

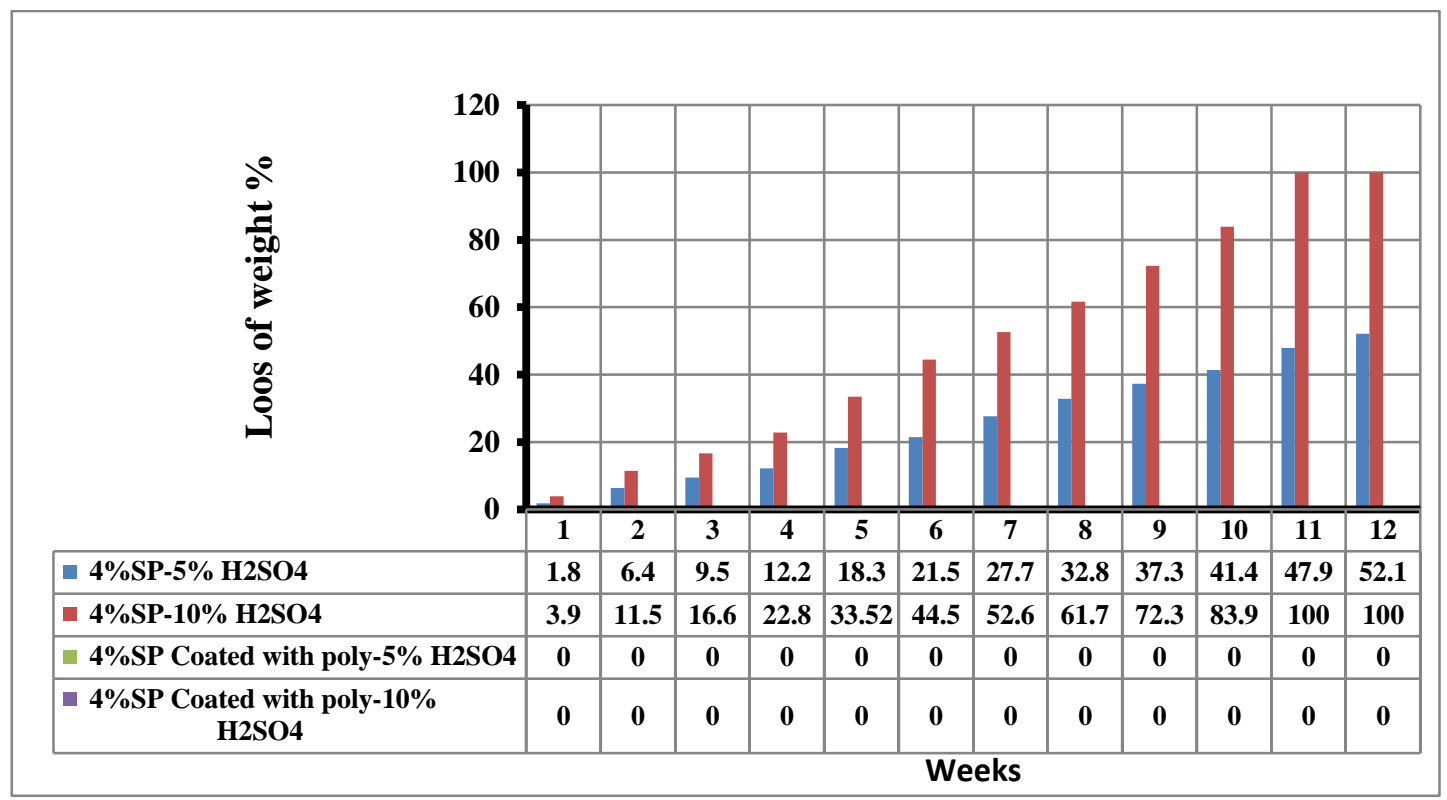

Figure 6: Explain the loss of weight for 4\%SP specimens coated with polyurethane immersed in diluted sulfuric acid with weeks.

\subsection{Effect of polyurethane coating and the type of mix material on the percentage of weight loss.}

Table 3-2 and Figure 3.1 show that the ratio of weight loss for submerged reference (uncoated with polyurethane paint) specimens in concentration (5 and 10) \% of sulfuric acid was 100\% in the eighth and fifth weeks respectively, while the ratio of weight loss was for the mix 4\% SP and immersed in concentration 5\% sulfuric acid $52 \%$ in the twelfth week but that the specimens submerged in concentration $10 \%$ of sulfuric acid were $100 \%$ in the eleventh week. The reason may be due to the addition of superplasticizer by $4 \%$ and the reduction of water /cement ratio from (48 to 28) \% increased the resistance to corrosion of sulfuric acid.

Figure 3.2 shows that the ratio of weight loss for submerged reference (for coated and un polyurethane coated) specimens in concentration (5 and 10)\% of sulfuric acid was $100 \%$ in the eighth and fifth weeks for uncoated respectively, while the ratio of weight loss (polyurethane coated) specimens immersed in concentration (5 and 10)\% of sulfuric acid were insignificant, The reason of reduction was due to the polyurethane coating of specimens which prevents the corrosion in these specimens .

Figure 3.3 shows that the ratio of weight loss for submerged reference (for coated and un polyurethane coated) specimens immersed in concentration (5 and 10) \% of sulfuric acid for the mix $4 \% \mathrm{SP}$ and immersed in concentration $5 \%$ sulfuric acid $52.1 \%$ in the twelfth week but that the specimens submerged in concentration $10 \%$ of sulfuric acid were $100 \%$ in the eleventh week. The reason may be due to the addition of superplasticizer by $4 \%$ and the reduction of water /cement ratio from (48 to 28 ) \% increased the resistance to corrosion of sulfuric acid. The specimens that were coated with polyurethane paint, whether from the reference mix or containing 4\%SP mix, showed very high resistance to corrosion. The ratio of weight loss for the submerged specimens in concentration (5 and 10) \% of sulfuric acid after the 12 th week was $0.0 \%$. This confirms that the polyurethane coating eliminates the corrosion problem in concrete pipes.

\section{Conclusions}

The specimens containing 4\% SP show resistance to corrosion sulfuric acid concentration (5 and 10) \% batter than reference mix. -The specimens that were coated with polyurethane paint, whether from the reference mix or containing $4 \% \mathrm{SP}$ mix, showed very high resistance to corrosion.

\section{References}

[1] Attiogbe K., E., and Rizkalla H., S., (1988), "Response of concrete to sulfuric acid attack" ACI Materials Journal, PP 481-488. 
[2] Bowlus, F., D., and Banta A., P., (1932), "Control of anaerobic decomposition in sewage transportation", Water Works Sewerage, 79 (11) 369.

[3] Cho, K., S., and Mori, T., (1995), "A newly isolated fungus participates in the corrosion of concrete sewer pipes", Water Science and Technology, 31(7) 263-271.

[4] Gu, J., D., Ford, T., E., et al. (1998), "Biodeterioration of concrete by the fungus fusarium", International Biodeterioration \& Biodegradation", 41(2) 101-109.

[5] Hewayde, E., Nehdi, M., et al. (2007), "Effect of mixture design parameters and wetting-drying cycles on resistance of concrete to sulfuric acid attack", Journal of Materials in Civil Engineering, 19(2) 155-163.

[6] Iraqi specification, No.5/1984., "Portland cement".

[7] Iraqi specification, No.45/1984., "Aggregate from natural sources for concrete and construction".

[8] Kaempfer W., and Berndt M., (1999) "Estimation of Service Life of Concrete in Sewer Networks", Institute of Material Research and Testing, Bauhaus University of Weimar, Germany.

[9] Nica, D., Davis, J., L., et al. (2000), "Isolation and characterization of microorganisms involved in the biodeterioration of concrete in sewers", Journal of International Biodeterioration \& Biodegradation, 46(1) 61-68

[10] Okabe, S., Odagiri, M., et al. (2007), "Succession of sulfuroxidizing bacteria in the microbial community on corroding concrete in sewer systems", Applied and Environmental Microbiology, 73(3) 971-980.

[11] Olmstead, W., M., and Hamlin, H. (1900), "Converting portions of the los angles outfall sewer into a septic tank", Engineering news, 44 317-318

[12] www.calucem.com 
